\title{
Management Boards and Indonesia's Company Innovation Performance
}

\author{
Desi Ilona $^{1}$, Zaitul Zaitul ${ }^{2 *}$, Eugene Okyere Kwakye ${ }^{3}$ \\ ${ }^{1}$ Economics and Business Faculty, Universitas Putra Indonesia YPTK, Indonesia \\ ${ }^{2}$ Economics and Business Faculty, Universitas Bung Hatta, Padang, Indonesia \\ ${ }^{3}$ Faculty of Business and Management Studies, Koforidua Technical University, Ghana
}

Article Info
Article history:
Received: 04 December 2020;
Accepted: 12 October 2021;
Published: 13 October 2021

Keywords:

Management board; Innovation performance; Indonesia's company

\begin{abstract}
This study aims to investigate the influence of the management board's characteristics on company innovation performance. Management board characteristics are female in the management board, education background, and Chinese ethnicity in the management board. Resources dependency theory is applied to understand the research phenomena. Using 109 companies listed in the Indonesian stock market, multivariate regression analysis was employed. This study also employed five control variables: family ownership, foreign ownership, company profitability, company leverage, and company size. The result shows that female in management board is negatively related to innovation performance. Besides, family ownership, company profitability, company leverage, and company size positively affect innovative performance.
\end{abstract}

\section{Abstrak}

Penelitian ini bertujuan untuk menguji pengaruh karakeristik dari Dewan Direksi terhadap kinerja inovasi perusahaan. Karakteristik Dewan Direksi diukur dengan tiga variabel yaitu perempuan di Dewan Direksi, latar belakang pendidikan Dewan Direksi, Etnik Cina di Dewan Direksi. Resources dependency theory digunakan untuk memahami pengaruh karakteristik Dewan Direksi terhadap kinerja inovasi perusahaan. 109 perusahaan yang terdaftar pada Bursa Efek Indonesia dijadikan sebagai sampel penelitian dan data diolah dengan menggunakan analisa regresi berganda. Penelitian ini juga menggunakan 5 variabel kontrol yaitu kepemilikan keluarga, kepemilikan asing, profitabilitas perusahaan, leverage perusahaan, dan ukuran perusahaan. Hasil penelitian menunjukan bahwa perempuan di Dewan Direksi berpengaruh negative terhadap kinerja inovasi. Selain itu, kepemilikan keluarga, profitabilitas perusahaan, leverage, dan ukuran perusahaan berpengaruh positif terhadap inovasi.

\section{How to Cite:}

Ilona, D., Zaitul, Z., \& Kwakye, E. O. (2021). Management Boards and Indonesia's Company Innovation Performance. Jurnal Pendidikan Ekonomi \& Bisnis, 9(2), 119-130. https://doi.org/10.21009/JPEB.009.2.4

* Corresponding Author: zaitul@bunghatta.ac.id Zaitul 


\section{INTRODUCTION}

Some companies today gain their competitive advantage through continuous innovation (Auh and Menguc, 2005). Corporate governance mechanisms can affect the values and motivations of managers regarding investment in strategies and practices (Mascena et al., 2020), including innovation strategy. Also, innovation is considered a crucial subscriber to the company's competitive advantage (Diaz-Fernandez et al., 2017). Liu et al. (2017) argue that innovation performance is linked to the innovation matrix with other pertinent organizations. Many sustainable companies have applied this strategy, such as Silicon Valley, and Toyota. The company has been gradually building a network to incline relationships with other organizational actors in professional, social, and exchange (Zheng et al., 2013). Powell et al. (1996) argue that innovation cautiously extends throughout inter-organizational networks. In brief, innovation is a key factor for a company's success (Li and Yang, 2019). Investment in new R\&D projects has long-term results for organizational viability and favourable outcome (Singh and Gaur, 2013). Company Innovation performance is measured by an intensive research and development (ratio of total $R \& D$ expenses over total revenue) (Chao et al., 2017; Chatterji et al., 2013; Y. Li et al., 2019), the amount of R\&D investment (Sarto et al., 2019), the number of patents (Kang et al., 2017), number of citations and claims (Balsmeier et al., 2017), and use the relevant indicators (Rejeb et al., 2020; Ruiz-Jimenez et al., 2016).

According to Upper-echelon theory, strategies for innovation are linked to the personal traits of the top management team (Kuo et al., 2017). Talke et al. (2010) argue that the configuration of top management teams influences innovation in a company. Besides, Ruiz-Jimenez et al. (2016) state that managers are the individuals who assemble strategic decisions and decide how to distribute the company resources. Therefore, they would select the projects, goals, and objectives to be accomplished (Ruiz-Jimenez et al., 2016). Hillman and Dalziel (2003) argue that a proper composition of the board may lessen unpredictability, intensify information change over between external companies and the company, expand access to resources and help to formulate the company's strategy.

Board diversity may build disagreement and conflict among professionals who bring about energetic information pursuit and processing (Midavaine et al., 2016). Singh and Gaur (2013) state that corporate governance mechanisms have contributed to innovation or R\&D decisions, especially from the corporate governance structure and practice perspectives. According to Kuo et al. (2017), corporate governance and incentive structure have a significant relationship with the company's R\&D investment decisions. Claessens et al. (2000) state that internal mechanisms govern companies from the emerging market due to the family and concentrated ownership of the company.

Innovation is a complex activity in which knowledge is used to gain a commercial target. Innovation performance is critical to maintaining the sustainable competitive advantage of a company. Creative input, process and output would make the company profitable. Innovation can be done in functional management areas, such as marketing, finance, human resources, and operations or production. Innovative functional management and product or service brings companies to higher innovation performance. Besides, innovation performance increases financial performance and competitive advantages.

Several theories explain why innovation performance varies among companies. Some companies have higher innovation performance, and others have lower innovation performance. From the Resources Dependency Theory (Zahra and Pearce, 1989), management contributes significantly in determining innovation performance. Besides, the supervisory board (Jensen and Meckling, 1976) could also influence the performance (e.g. Agency theory). Resources based theory (Barney, 1991) can also predict the innovative performance of the company. Variables from the resources dependency theory (Zahra and Pearce, 1989) are management board characteristics, such as female involvement, education background, and ethnicity in the management board.

The concept of the management board is derived from the corporate governance board. There are two corporate governance systems: The Anglo-Saxon corporate governance system and the Continental Europe system (Ilona et al., 2019; Zaitul and Ilona, 2019). The Continental Europe corporate governance system applies a two-tier board system: a supervisory board and a 
management board. Management boards run the day-to-day company business, and the supervisory board controls them. In addition, the management board initiate the business ideas and execute the decisions made by the supervisory board through ratification. The supervisory board monitors the execution. The management board plays a significant role by building an innovative product or service and process.

A Female on the management board implies that a female participates as a member of the company management board. Females on the board carry diverse perspectives to the board booth and ease more informed decisions (Daily et al., 2000). Besides, the female board member also performs a different style of decision making (Peterson and Philpot, 2007). However, a female has a higher risk aversion in financial decision making (Srinidhi et al., 2011). Farrell and Hersch (2005) argue that there is no effect on the female inboard on company value. It is supported by (Issa et al., 2021), who believe that homogeneous board members contribute to better strategic decisions. In innovation, females on the management board restricted the number of financial resources used for innovation (Luo et al., 2020) due to their perception toward R\&D project risk. Therefore, the presence of females in the management board reduced the innovation activities.

Finally, females in the management board decreased innovation performance. Management board members with economics, management and accounting backgrounds tend to perform better at innovation. A management board with this kind of educational background know about sources of the company's competitive advantages: Innovation. Therefore, they plan, organize, lead, and control innovation activities. Finally, it improves innovation performance. Chinese on the management board regards persons of Chinese ethnicity participating in the management board. Even though the Chinese population in Indonesia is around 3\%, they control the wealth. There is some benefit of having Chinese ethnicity participating on the board. Chinese board members profess great leadership skills as a professional managers and can manage the company to gain a competitive advantage (Melmusi et al., 2019).

Previous studies have investigated the relationship management board characteristics are still lacking. Ruiz-Jimenez et al. (2016) investigate the effect of females on the management board on company performance and concluded that females on the management board do not affect innovation. However, Torchia et al. (2018) document a positive relationship between female on a management board and organizational innovation performance. In addition, (Rejeb et al., 2020) conclude that there is no effect of females on board on companies innovation. However, when females are on board as a moderating variable, they succeed in moderating the relationship between board role (service role and control role) and company innovation (Rejeb et al., 2020).

The majority of several studies investigating companies' performance in terms of innovation are conducted in the developed market (Balsmeier et al., 2014, 2017; Chao et al., 2017; C. Chen et al., 2016; J. Chen et al., 2018; Jajja et al., 2017; Kuo et al., 2018; Y. Li et al., 2019; Midavaine et al., 2016; Rejeb et al., 2020; Ruiz-Jimenez et al., 2016; Sarto et al., 2019; Teixeira and Bezerra, 2016; Torchia, Calabrò, Gabaldon, and Kanadli, 2018). However, there is a lack of prior studies exploring management boards and innovation performance in the Indonesian context. In addition, the woman on the company board as determinants of companies innovation was investigated by limited previous studies (Rejeb et al., 2020; Ruiz-Jimenez et al., 2016; Torchia, Calabrò, Gabaldon, \& Bogac, 2018). However, they study the women on the board of directors and company innovation mostly in one-tier board system (Continental Europe corporate governance system). Balsmeier et al. (2014) investigate the role of the external supervisory board in determining the innovative performance of German companies. Balsmeier et al. (2017) study the effect of the independent board of directors on innovation. Chao et al. (2017) investigate the relationship between corporate governance and innovation performance. It can be concluded that there exists a significant effect of innovation investment on innovation performance. Chen et al. (2016) analyse the relationship between independent board members and the innovative performance of Taiwanese companies. Chen et al. (2018) investigate the influence of female board representation on innovation and firm performance.

Further, Jajja et al. (2017) conclude that innovation strategy influences innovation performance. Also, Kuo et al. (2018) investigate the effect of an educated director on R\&D investment. Midavaine et al. (2016) investigate the relationship between board diversity and company investment in R\&D. Ruiz-Jimenez et al. (2016) document that the relationship between 
knowledge combination capabilities and innovation. Teixeira and Bezerra (2016) report that the sources of Portuguese's company innovation performance are companies' openness and the relative importance attributed to different sources of information for innovation. Torchia et al. (2018) study the effect of women directors on the innovation performance of Norwegian companies. Li et al. (2019) investigate the relationship between technology director and innovation performance in China and found that technology director has a significant effect on company innovation performance. Sarto et al. (2019) also analyses Italian companies' innovation performance and concludes that heterogeneity of educational and functional director background affects the company innovation. Finally, Rejeb et al. (2020) investigate the board role on Tunisian listed companies and resume that gender diversity and board independent partially moderated the relationship between board role and companies innovation.

There are two corporate governance board systems in the world: the one-tier board system and the two-tier board system. According to Indonesia's corporate law, the two-tier board system is prescribed for companies: a supervisory board (Dewan Komisaris) and a management board (Dewan Direksi) (Darmadi, 2013). The management board performs the day-to-day management in a company. Zaitul and Ilona (2018) argue that Indonesia adapts to the Continental European system. As the largest economy in Southeast Asia and the 16th-largest globally (Darmadi, 2016), Indonesia has been attracting foreign investors. However, the innovative process and output among Indonesian' company is still low. From preliminary assessment, we found that the average percentage investment on $R \& D$ expenditure per sale/revenue is very low (below $1 \%$ ). That as an emerging capital market, it is characterized by weak external corporate governance mechanisms, such as inadequate legal systems and law enforcement and investor protection (La Porta et al., 1999). Previous studies focused less on the relationship between the management board and innovation performance using the unique Continental European corporate governance system. Therefore, this study investigates the relationship between management board characteristics: Females in the management board, Education background of the management board, Chinese ethnicity in the management board, and innovation performance.

The study about the effect of the education management board on innovation performance is still lacking. Midavaine et al. (2016) investigate the relationship between the educational diversity of a board and innovation and concluded that education diversity makes the company invest more in innovative processes. Previous research on the existence of Chinese ethnicity on a management board and innovation performance is also still lacking. Based on theory and previous study, we developed the following hypotheses:

$\mathbf{H}_{1}$ : Management boards have a significant effect on company innovation performance

$\mathbf{H}_{1 \mathrm{a}}$ : Females on management boards have a negative relationship with innovation performance

$\mathbf{H}_{1 \mathbf{b}}$ : Educational background of management boards positively relates to innovation performance

$\mathbf{H}_{1 \mathbf{c}}$ : Chinese ethnicity in management boards increases innovation performance

\section{METHOD}

The Companies listed in Indonesia's stock exchange were the object of the research object. The purposive sampling method was applied to gain the final sample. This study uses financial and non-financial disclosure data. The first criteria are that the companies consistently disclose their R\&D investment, sex type, education background, and ethnic of management board, and ownership information. Second criteria, the companies release the annual report every year. Finally, the companies were not delisted during the study period. The final sample is 109 companies or 327 companies-year (observation). The type of data used in this study is secondary data, collected over three years.

There are three kinds of variables under discussion: dependent variable (innovation performance), independent variables (management board) and control variables (company's characteristics). Innovation performance was measured by intensive research and development (ratio of total R \& D expenses over total revenue) (Chao et al., 2017; Chatterji et al., 2013; Y. Li et al., 2019). While, (Sarto et al., 2019) employs the amount of R\&D investment to measure innovation performance. Other studies use other measurements of company innovation, such as number of 
patents (Kang et al., 2017), number of citations and claims (Balsmeier et al., 2017), and use the relevant indicators (Rejeb et al., 2020; Ruiz-Jimenez et al., 2016). Thus, the current study follows prior research of (Chao et al., 2017; Chatterji et al., 2013; Y. Li et al., 2019) that use the ratio of total $\mathrm{R} \& \mathrm{D}$ expenses over total revenue to measure innovation performance.

Besides, females, educational background, and ethnicity are proxies of the management board. Female in management board is calculated by ratio upon the number of female members in management board divided by a total member of the management board (Rejeb et al., 2020; RuizJimenez et al., 2016; Torchia, Calabrò, Gabaldon, and Bogac, 2018). The number of management board members with business education backgrounds is divided by the total member is a proxy for the education background of the management board (Ujunwa et al., 2012). Thus, ethnicity is measured by the number of Chinese ethnic members of the management board to a total member of the management board is a measurement for ethnicity (Wellalage et al., 2012). Aside from company characteristics are foreign ownership, family ownership, company profitability, size, and leverage. We also use the proportional approach (Choi et al., 2007; Colpan and Yoshikawa, 2012). In addition, company profitability uses the return on asset (ROA) as a proxy (Chi et al., 2019a; Kang et al., 2017). Moreover, company size is measured by total assets (Lodh et al., 2014; Rejeb et al., 2020; Sarto et al., 2019). Finally, leverage is the debt to asset ratio (Li et al., 2019; Muthuveloo et al., 2017).

This study used the multivariate regression model. After that, the regression analysis was applied to a panel data approach. The normality, multicollinearity and heteroscedasticity test (Hair et al., 2014) is tested in advance. In addition, the data is examined first its outlier using the Grubb approach (Grubbs, 1969). Then, the normality using univariate test by applying KolmogorovSmirnov test and not normal data is proceeded to be tested using the skewness per standard error with a value greater than 3.59 considered normal (Manning and Munro, 2004).

The next classical assumption is heteroskedasticity, and this research using the variance inflation factor (VIF) value. If the VIF value for each variable is lesser than 10 , it can conclude that there is no correlation among independent variables (Gujarati, 1995). Further, the heteroskedasticity problem is detected using the White test (White, 1980) with a p-value greater than 0.05 . Research findings were based on $p$-value, where the $p$-value is lesser than 0.05 , indicating that the independent variable has a significant effect on dependent variables (Sekaran, 2013) - the direction of the impact of the independent variable on the dependent variable based on the coefficient regression.

\section{RESULTS AND DISCUSSION}

The observation number of this study is 327 companies-years-table 1 summary of the research variables. The means value of IDR is $0.80 \%$, with a minimum and maximum value of $0.00 \%$ and $6 \%$, respectively. The average value of females on the management Board and educational background of the management board is $16.40 \%$ and $73.20 \%$, respectively. Ethnicity on the management board has an average value of $62.30 \%$ and $29.26 \%$ of family ownership. Average foreign ownership is $23.62 \%$, with a minimum and maximum value of $0.00 \%$ and $23.62 \%$, respectively. Further, average company profitability, leverage, and size are $3.72 \%, 52.39 \%$ and Rp. 1,7774.80 billion, respectively. 
Table 1. Descriptive Analysis and Outlier test

\begin{tabular}{lcccccc}
\hline \multirow{2}{*}{ Variables } & \multicolumn{3}{c}{ Descriptive statistic } & \multicolumn{2}{c}{ Outlier test } \\
\cline { 2 - 7 } & Min & Max & Means & SD & \# obs & \% \\
\hline IDR (\%) & 0.00 & 6.00 & 0.80 & 0.81 & 43.00 & 13.19 \\
FMB (\%) & 0.00 & 67.00 & 16.40 & 19.50 & 0.00 & 0.00 \\
EBMB (\%) & 0.17 & 1.00 & 73.20 & 21.90 & 0.00 & 0.00 \\
CEMB (\%) & 0.00 & 1.00 & 62.30 & 28.60 & 0.00 & 0.00 \\
FO (\%) & 0.00 & 85.00 & 29.26 & 29.57 & 10.00 & 3.07 \\
Fro (\%) & 0.00 & 83.23 & 23.62 & 26.14 & 14.00 & 4.29 \\
Pro (\%) & -22.23 & 30.60 & 3.72 & 6.68 & 22.00 & 6.75 \\
Lev (\%) & 6.00 & 92.00 & 52.39 & 24.08 & 5.00 & 1.53 \\
CS (Rp. billion) & 1.30 & $26,185.50$ & $1,774.80$ & 412.61 & 110.00 & 33.74 \\
\hline
\end{tabular}

Notes: IDR (intensity research \& development), FMB (female in management board), EBMB (education background of the management board), CEMB (Chinese ethnic in management board), FO (family ownership), Fro (foreign ownership), Pro (company profitability), Lev (company leverage), and CS (company size)

Before proceeding to the regression analysis, the data were tested for the outlier. In this case, the Grubbs test was applied to detect and remedy the data (Grubbs, 1969). The result is also shown in Table 1. Management Board proxy is free from outliers. However, IDR was detected for 43 outliers (13.19\%). The detected outlier for FO, Fro, Pro, Lev and company size is $3.07 \%, 4.29 \%, 6.75 \%, 1.53 \%$, and $33.74 \%$, respectively.

Having cleared the outlier data, the classical assumption test was conducted (normality, multicollinearity, and heteroscedasticity). For the normality test, this study used the KolmogorovSmirnov test, where the asym Sig must be greater than 0.05 for the data to be considered normal. Looking on Table 2, the result shows that only one variable is normal (leverage). Therefore, the skewness per standard error (Manning and Munro, 2004) was run to test the normality. The result indicated that the four variables were normal (EBMB, CEMB, FO, and CS). Un-normal data was transformed into a natural logarithm (Ln) and square root (Sqrt). Using the skewness per standard error, the rest of the variables were normal due to the value of skewness per standard error which was lesser than 3.59 (Manning and Munro, 2004).

Table 2. Normality Test

\begin{tabular}{|c|c|c|c|c|c|c|c|}
\hline \multirow[t]{2}{*}{ variables } & \multicolumn{2}{|c|}{ Kolmogorov-Smirnov } & \multicolumn{2}{|c|}{$\begin{array}{l}\text { Skewness/ } \\
\text { standard error }\end{array}$} & \multicolumn{2}{|c|}{$\begin{array}{l}\text { Skw/SE post- } \\
\text { transformation }\end{array}$} & \multirow[t]{2}{*}{$\begin{array}{c}\text { Final } \\
\text { decision }\end{array}$} \\
\hline & A sym Sig & Decision & Value & Decision & Ln & sqrt & \\
\hline IDR & 0.00 & not normal & 66.99 & not normal & 2.59 & - & normal \\
\hline FMB & 0.00 & not normal & 6.76 & not normal & 0.30 & - & normal \\
\hline EBMB & 0.00 & not normal & -1.46 & normal & - & - & normal \\
\hline CEMB & 0.00 & not normal & -0.87 & normal & - & - & normal \\
\hline FO & 0.00 & not normal & 3.53 & normal & - & - & normal \\
\hline Fro & 0.00 & not normal & 7.38 & not normal & - & 1.30 & normal \\
\hline Pro & 0.00 & not normal & 6.47 & not normal & - & 3.50 & normal \\
\hline Lev & 0.07 & normal & - & - & - & - & normal \\
\hline $\mathrm{CS}$ & 0.00 & not normal & 2.63 & normal & - & - & normal \\
\hline
\end{tabular}

Notes: IDR (intensity research \& development), FMB (female in management board), EBMB (education background of the management board), CEMB (Chinese ethnic in management board), FO (family ownership), Fro (foreign ownership), Pro (company profitability), Lev (company leverage), and CS (company size)

The second classical assumption was multicollinearity. In this study, we used the variance inflation factor (VIF). The value of VIF is lesser than 10, indicating that there was no 
multicollinearity problem (Gujarati, 1995). The result in Table 4 shows that all VIF values were lesser than ten, so there was no multicollinearity problem.

Table 3. Result of Heteroscedasticity Test

\begin{tabular}{lc}
\hline & Model \\
\hline Chi-Square & 61.841 \\
white test P-value & 0.39 \\
Ho (null) & Rejected \\
\hline
\end{tabular}

The last classical assumption test was heteroscedasticity. The test of heteroscedasticity uses the white test (White, 1980). If the White test p-value is greater than 0.05, the model is considered free from any heteroscedasticity problem. Table 3 shows that the White test $p$-value is higher than 0.05 , and it can be concluded that there is no problem with heteroscedasticity. The hypotheses were tested using multiple regression, and the results can be seen in Table 4 . The fitness of the model using the $\mathrm{F}$ statistic and $\mathrm{F}$ significance show that the model was fit. This is because the $\mathrm{F}$ significance is lesser than 0.05. Regarding model power, 93.79\% variance of the dependent variable could be explained by independent variables; the rest was explained by other variables not included in this study.

Table 4. Result of Regression

\begin{tabular}{lccccc}
\hline Variables & VIF & Coefficient & SE & t stat & Decision \\
\hline Constant & - & -0.004 & 0.002 & -2.329 & - \\
FMB & 1.32 & -0.002 & 0.001 & $-2.644^{* * *}$ & supported \\
EBMB & 1.08 & 0.002 & 0.001 & 1.234 & not supported \\
CEMB & 1.12 & -0.001 & 0.001 & -0.596 & not supported \\
FO & 1.23 & 0.000 & 0.000 & $4.035^{* * *}$ & supported \\
Fro & 1.07 & 0.000 & 0.000 & 1.255 & not supported \\
Pro & 1.48 & 0.000 & 0.000 & $2.736^{* * *}$ & significant \\
Lev & 1.72 & 0.000 & 0.000 & $5.060^{* * *}$ & significant \\
CS & 1.34 & 0.000 & 0.000 & $5.968^{* * *}$ & significant \\
F statistic & \multicolumn{7}{c}{253.113} & & \\
F sig & \multicolumn{7}{c}{0.000} & & \\
R square & \multicolumn{7}{c}{93.79} & & \\
\hline
\end{tabular}

Note: IDR (intensity research \& development), FMB (female in management board), EBMB (education background of the management board), CEMB (Chinese ethnic in management board), FO (family ownership), Fro (foreign ownership), Pro (company profitability), Lev (company leverage), and CS (company size).

The effect of the management boards on innovation performance could be seen from the value of $t$ statistics from the regression result. Table 4 shows that the first hypothesis on the female management boards and innovation performance is accepted with statistical tests at the $5 \%$ level and $t$ statistics is -2.644. It indicates that female management boards have a negative effect on innovation performance. Thus, the higher the number of females on the management board, the lower the rate of innovation performance. The possible argumentation is that the female on the management board would limit the financial resources invested for innovation due to the perception of the high investment risk. Therefore, it reduces innovation activities. However, women on the governance board are effective for accounting quality, ethical and social responsibility of companies. This finding is not consistent with the finding of (Rejeb et al., 2020; Torchia, Calabrò, Gabaldon, and Kanadli, 2018), which documented a positive effect of females on organization performance. However, women on board success moderated the relationship between board role and company innovation (Rejeb et al., 2020). Also, Ruiz-Jimenez et al. (2016) found no association between women on board and company innovation. 
This study finds an insignificant relationship between the educational background of the management board and innovation performance. This result is supported by the prior research of (Issa et al., 2021). They find that the education background of the management board has no significant impact on bank performance listed in the MENA (the Middle East and North Africa) countries. A high level of management boards' education may benefit creating innovation and information but is not the case in increasing the quality of strategic taken by management board in Indonesians' companies. For the third hypothesis, this research found that Chinese ethnic in management board also does not benefit in increasing innovation performance. This result is opposite to the prior finding of (Zaitul et al., 2021), who find that ethnic diversity has a negative impact on international decisions. And this is the first study that includes the Chinese ethnic on the management board as a predictor of company innovation performance.

Regarding control variables, family ownership seems to be a critical variable in increasing innovation performance. Contradict to the argumentation of (Asensio-López et al., 2019) that family owners have an information advantage and better understand the R\&D project value and risk. Therefore, to maintain the certain future performance for the next generation, it is difficult for them to diversify their risk (Tsao et al., 2014). They prefer to invest less in the R\&D project and reduce the innovation performance. The possible argumentation of positive effect is that many of family firm is the hand of descendant. Thus, they see R\&D risk differently compared to the founder. So, they like to invest in R\&D project to maintain the future sustainability. The second control variable (Foreign ownership) do not have a significant effect on company innovation. Even though there is an argumentation that foreign owner bring an advanced techniques, knowledge and management resources to the company and these resources will improve the company performance, including the innovation performance (Asensio-López et al., 2019). However, this is not the case for an Indonesia's company.

The results in Table 4 show that company size has a positive and significant impact on innovation performance. This finding is in line with previous studies (Aggarwal et al., 2012; Balsmeier et al., 2017; Chen et al., 2016; Li \& Yang, 2019; Li et al., 2019; Lodh et al., 2014; Sarto et al., 2019; Wei et al., 2019). It implies that a large company tends to have higher innovation performance due to the large resources. In addition, the company leverage has a positive effect on company innovation performance. This finding is supported by previous studies (Chi et al., 2019a; Kang et al., 2017; Sarto et al., 2019). But it has a contrasting result (negative effect) compared to previous studies (Balsmeier et al., 2017; Y. Li et al., 2019; Wei et al., 2019). Finally, the company profitability also has a positive relationship with the company innovation performance. This finding is consistent with the previous studies (Chi et al., 2019b; Kang et al., 2017) and differ with the finding of $\mathrm{Li}$ et al. (2019) and Wei et al. 2019) who conclude that there is a negative effect of company profitability and company innovation performance.

\section{CONCLUSIONS AND SUGGESTION}

Nowadays, a company has to innovate products or services to sustain a competitive advantage. The company should have an innovative process and active research and development function. The previous study paid less attention to Indonesia, where a unique Continental Europe Corporate Governance system is applied. This study investigated the relationship between the management board characteristics and innovation performance. The results show that only females in management boards have a significant effect on innovation performance. In addition, the impact of females on management boards on innovation performance was negative.

This finding implies that females on the management board tend to limit the financial resources invest in $R \& D$ projects and reduce the innovation activities. Higher innovation performance can result from higher family ownership, higher company profitability, higher company leverage, and a larger company. This finding enriches the resources dependence theory. This study uses a limited sample. Future research can add the number of samples to get a robust result. Furthermore, future investigations can look at innovation performance from other perspectives, such as the resource-based or agency perspective. 


\section{REFERENCES}

Aggarwal, R. A. J., Cao, J., \& Chen, F. (2012). Information Environment, Dividend Changes , and Signaling: Evidence from ADR Firms. Contemporary Accounting Research, 29(2), 403-431. https://doi.org/10.1111/j.1911-3846.2011.01101.x

Asensio-López, D., Cabeza-García, L., \& González-Álvarez, N. (2019). Corporate governance and innovation: a theoretical review. European Journal of Management and Business Economics, 28(3), 266-284. https://doi.org/10.1108/EJMBE-05-2018-0056

Auh, S., \& Menguc, B. (2005). Top management team diversity and innovativeness : The moderating role of interfunctional coordination. Industrial Marketing Management, 34, 249-261. https://doi.org/10.1016/j.indmarman.2004.09.005

Balsmeier, B., Buchwald, A., \& Stiebale, J. (2014). Outside directors on the board and innovative firm performance. Research Policy, 43, 1800-1815. https://doi.org/10.1016/j.respol.2014.06.003

Balsmeier, B., Fleming, L., \& Manso, G. (2017). Independent boards and innovation. Journal of Financial Economics, 123(3), 536-557. https://doi.org/10.1016/j.jfineco.2016.12.005

Barney, J. B. (1991). Firm Resources and Sustained Competitive Advantage. In Journal of Management (Vol. 17, Issue 1, pp. 99-120). https://doi.org/10.1177/014920639101700108

Chao, S., Jian, J., \& Xin, G. (2017). Empirical analusis of corporate governance and innovation performance in solar photovoltaic enterprise. Light \& Enggineering, 25(3), 57-64.

Chatterji, a., Listokin, S., Ringov, D., Zollo, M., Purdy, J. M., Gray, B., Marcus, J., Kurucz, E. C., Colbert, B. a., Yang, X., Rivers, C., Bondy, K., Moon, J. J. J., Matten, D., Wang, Z., Zhang, X., Wang, R., Kang, H., Qiao, B., ... Jones, M. T. (2013). Integrated and decoupled corporate social performance: Management ... Journal of Business Ethics, 66(1), 1-9. https://doi.org/10.5465/AMR.2007.24345254

Chen, C., Lin, B., Lin, Y., \& Hsiao, Y. (2016). Ownership structure , independent board members and innovation performance: A contingency perspective. Journal of Business Research, 69(9), 3371-3379. https://doi.org/10.1016/j.jbusres.2016.02.007

Chen, J., Leung, W. S., \& Evans, K. P. (2018). Female board representation , corporate innovation and firm performance. Journal of Empirical Finance, 48, 236-254. https://doi.org/10.1016/j.jempfin.2018.07.003

Chi, J., Liao, J., \& Yang, J. (2019a). Institutional stock ownership and firm innovation : Evidence from China. Journal of Multinational Financial Management, 50, 44-57. https://doi.org/10.1016/j.mulfin.2019.04.003

Chi, J., Liao, J., \& Yang, J. (2019b). Institutional stock ownership and firm innovation: Evidence from China. Journal of Multinational Financial Management, 50, 44-57. https://doi.org/10.1016/j.mulfin.2019.04.003

Choi, J. J., Park, S. W., \& Yoo, S. S. (2007). The Value of Outside Directors: Evidence from Corporate Governance Reform in Korea. Journal of Financial \& Quantitative Analysis, 42(4), 941-962. https://doi.org/10.2307/27647330

Claessens, S., Djankov, S., \& Lang, L. H. P. (2000). The separation of ownership and control in East Asian Corporations. Journal of Financial Economics, 58, 81-112.

Colpan, A. M., \& Yoshikawa, T. (2012). Performance Sensitivity of Executive Pay: The Role of Foreign Investors and Affiliated Directors in Japan. Corporate Governance An International Review, 20(6), 547-561.

Daily, C. M., Certo, S. T., \& Dalton, D. R. (2000). The future of corporate women: Progress toward the executive suite and the boardroom? In Women on corporate boards of directors: International challenges and opportunities (pp. 11-23). Kluwer Academic Publishers.

Darmadi, S. (2013). Do women in top management affect firm performance? Evidence from 
Indonesia. Corporate Governance: The International Journal of Business in Society, 13(3), 288304. https://doi.org/10.1108/CG-12-2010-0096

Darmadi, S. (2016). Ownership concentration, family control, and auditor choice: Evidence from an emerging market. Asian Review of Accounting, 24(1), 19-42.

Diaz-Fernandez, M., Bornay-Barrachina, M., \& Lopez-Cabrales, A. (2017). HRM practices and innovation performance: a panel-data approach. International Journal of Manpower, 38(3), 354-372. https://doi.org/10.1108/IJM-02-2015-0028

Farrell, K. A., \& Hersch, P. L. (2005). Additions to corporate boards: The effect of gender. Journal of Corporate Finance, 11(1-2), 85-106. https://doi.org/10.1016/j.jcorpfin.2003.12.001

Grubbs, F. F. (1969). Procedures for Detecting Outlying Observations in Samples. Tachometric, 11(1), 1-21.

Gujarati, D. (1995). Basic Econometric. McGraw-Hill.

Hair, J. F., William, C., Babin, B. J., \& Anderson, R. E. (2014). Multivariate Data Analysis (7th Editio). Pearson Education Limited.

Hillman, A. M. Y. I., \& Dalziel, T. (2003). Boards of Directors and Firm Performance : Integrating Agency and Resource Dependence Perspectives. Academy of Management Review, 28(3), 383396. https://doi.org/10.5465/AMR.2003.10196729

Ilona, D., Zaitul, \& Ethika. (2019). Supervisory board and company borrowing: the case of developing economics. Journal of Reviews on Global Economics, 8, 730-738.

Issa, A., Yousef, H., Bakry, A., Hanaysha, J. R., \& Sahyouni, A. (2021). Does the board diversity impact bank performance in the MENA countries? A multilevel study. Corporate Governance (Bingley), 21(5), 865-891. https://doi.org/10.1108/CG-06-2020-0222

Jajja, M. S. S., Kannan, V. R., Brah, S. A., \& Hassan, S. Z. (2017). Linkages between firm innovation strategy, suppliers, product innovation, and business performance: Insights from resource dependence theory. International Journal of Operations \& Production Management, 37(8), 1054-1075.

Jensen, M., \& Meckling, W. (1976). Theory of the firm: managerial behavior, agency costs, and ownership structure. Journal of Financial Economics, 3(4), 305-360. https://doi.org/10.1017/CBO9780511817410.023

Kang, J., Liu, W., Low, A., \& Zhang, L. (2017). Friendly Boards and Innovation. Journal of Empirical Finance, 45, 1-25. https://doi.org/10.1016/j.jempfin.2017.09.007

Kuo, H., Wang, L., \& Yeh, L. (2017). The role of education of directors in in fl uencing fi rm R \& D investment. Asia Pacific Management Review, 30, 1-13. https://doi.org/10.1016/j.apmrv.2017.05.002

Kuo, H., Wang, L., \& Yeh, L. (2018). The role of education of directors in influencing firm R\&D investment. Asia Pacific Management Review, 23(2), 108-120. https://doi.org/10.1016/j.apmrv.2017.05.002

La Porta, R., Lopez-De-Silanes, F., \& Shleifer, A. (1999). Corporate Ownership Around the World. The Journal of Finance, 54(2), 471-517. https://doi.org/10.1111/0022-1082.00115

Li, M., \& Yang, J. (2019). Effects of CEO duality and tenure on innovation. Journal of Strategy and Management, 12(4), 536-552. https://doi.org/10.1108/JSMA-04-2019-0049

Li, Y., Liu, Y., \& Xie, F. (2019). technology directors and firm innovation. Journal of Multinational Financial Management, 50, 76-88. https://doi.org/10.1016/j.mulfin.2019.04.001

Liu, X., Shen, M., Ding, W., \& Zhao, X. (2017). Tie strength, absorptive capacity and innovation performance in Chinese manufacturing industries. Nankai Business Review International, 8(4), 475-494. https://doi.org/10.1108/NBRI-01-2017-0002

Lodh, S., Nandy, M., \& Chen, J. (2014). Innovation and Family Ownership : Empirical Evidence 
from India. Corporate Governance: An International Review, 22(1), 4-23. https://doi.org/10.1111/corg.12034

Luo, J. hui, Peng, C., \& Zhang, X. (2020). The impact of CFO gender on corporate fraud: Evidence from China. Pacific Basin Finance Journal, 101404. https://doi.org/10.1016/j.pacfin.2020.101404

Manning, M. L., \& Munro, D. (2004). The business survey researcher's SPSS cookbook (2nd ed). Pearson Education.

Mascena, K. M. C. de, Barakat, S. R., Isabella, G., \& Fischmann, A. A. (2020). The Influence of Board Structure and Ownership Concentration on GRI Reporting. REVISTA BRASILEIRA DE GESTÃO DE NEGÓCIO; 2020: AHEAD OF PRINT, 1-20. https://doi.org/10.7819/rbgn.v0i0.4065

Melmusi, Z., Ilona, D., Elfiswandi, \& Kurniawan, A. (2019). Do Diversity of Directors Improve Market Performance. The First Economics, Law, Education and Humanities International Conference, 2019, 125-136. https://doi.org/10.18502/kss.v3i14.4303

Midavaine, J., Dolfsma, W., \& Aalbers, R. (2016). Board diversity and R \& D investment. Management Decision, 54(3), 558-569.

Muthuveloo, R., Chiek, K. C., \& Ping, T. A. (2017). An Empirical Analysis of the Perceived Skills in Predicting Managerial Effectiveness: The Malaysian Perspective. Global Business and Management Research: An International Journal, 9(4s), 41-60.

Peterson, C. A., \& Philpot, J. (2007). Women's roles on U.S. Fortune 500 boards: Director expertise and committee memberships. Journal of Business Ethics, 72(2), 177-196. https://doi.org/10.1007/s10551-006-9164-8

Powell, W. W., Koput, K. W., \& Smith-doerr, L. (1996). Interorganizational and the collaboration and the locus of innovation: networks of learning in Biotechnology. Administrative Science Quarterly, 41(1), 116-145.

Rejeb, W. Ben, Berraies, S., \& Talbi, D. (2020). The contribution of board of directors' roles to ambidextrous innovation: Do board's gender diversity and independence matter? European Journal of Innovation Management, 23(1), 40-66. https://doi.org/10.1108/EJIM-06-2018-0110

Ruiz-Jimenez, J. M., Fuentes-Fuentes, M. del M., \& Ruiz-arroyo, M. (2016). Knowledge Combination Capability and Innovation: The Effects of Gender Diversity on Top Management Teams in Technology-Based Firms. Journal of Business Ethics, 135(3), 503-515. https://doi.org/10.1007/s10551-014-2462-7

Sarto, F., Saggese, S., Viganò, R., \& Mauro, M. (2019). Human capital and innovation: mixing apples and oranges on the board of high-tech firms. Management Decision, 58(5), 897-926. https://doi.org/10.1108/MD-06-2017-0594

Sekaran, U. (2013). Reserch Methods For Business.

Singh, D. A., \& Gaur, A. S. (2013). Governance Structure , Innovation and Internationalization: Evidence From India. Journal of International Management, 19(3), 300-309. https://doi.org/10.1016/j.intman.2013.03.006

Srinidhi, B., Gul, F. A., \& Tsui, J. (2011). Female directors and earnings quality. Contemporary Accounting Research, 28(5), 1610-1644. https://doi.org/10.1111/j.1911-3846.2011.01071.x

Talke, K., Salomo, S., \& Rost, K. (2010). How top management team diversity affects innovativeness and performance via the strategic choice to focus on innovation fields. Research Policy, 39(7), 907-918. https://doi.org/10.1016/j.respol.2010.04.001

Teixeira, A. A. C., \& Bezerra, L. (2016). Innovation performance in service companies and KIBS visà-vis manufacturing: the relevance of absorptive capacity and openness. REVISTA BRASILEIRA DE GESTÃO DE NEGÓCIOS, 18(59), $43-66$. https://doi.org/10.7819/rbgn.v18i59.2215 
Torchia, M., Calabrò, A., Gabaldon, P., \& Bogac, S. (2018). Women directors contribution to organizational innovation: A behavioral approach. Scandinavian Journal of Management, 34(2), 215-224. https://doi.org/10.1016/j.scaman.2018.02.001

Torchia, M., Calabrò, A., Gabaldon, P., \& Kanadli, S. B. (2018). Women directors contribution to organizational innovation: A behavioral approach. Scandinavian Journal of Management, 34(2), 215-224. https://doi.org/10.1016/j.scaman.2018.02.001

Ujunwa, A., Okoyeuzu, C., \& Nwakoby, I. (2012). Corporate board diversity and firm performance: Evidence from Nigeria. Review of International Comparative Management, 13(4), 606-620. https://doi.org/10.22495/cocv9i2c1art6

Wei, Y., Kang, D., \& Wang, Y. (2019). Geography, culture, and corporate innovation. Pacific-Basin Finance Journal, 56, 310-329. https://doi.org/10.1016/j.pacfin.2019.06.010

Wellalage, N. H., Locke, S., \& Scrimgeour, F. (2012). The Global Financial Crisis Impact on Ethnic Diversity of Sri Lanka Boards. Asian Journal of Finance \& Accounting, 4(1), 52-69. https://doi.org/10.5296/ajfa.v4i1.1243

White, H. (1980). A heteroskedasticity-consistent covariance matrix estimator and a direct test for heteroskedasticity. Econometrica, 48(4), 817-838.

Zahra, S. A., \& Pearce, J. A. (1989). Boards of directors and corporate financial performance: A review and integrative model. Journal of Management, 15(2), 291-334. https://doi.org/0803973233

Zaitul, \& Ilona, D. (2018). Gender in Audit Committee and Financial Reporting Timeliness : the Case of Unique Continental European Model. International Journal of Engineering \& Technology, 7(2.29), 436-442. https://doi.org/10.14419/ijet.v7i2.29.13668

Zaitul, \& Ilona, D. (2019). Tax Aggressiveness and Politically Connected Company. The 1st Economics, Law, Education and Humanties Internaltional Conference, 2019, 10-19. https://doi.org/10.18502/kss.v3i14.4294

Zaitul, Melmusi, Z., \& Ilona, D. (2021). Board Governance Diversity and the International Decision of Indonesia's Service Companies. Estudios de Economia Aplicada, 39(4). https://doi.org/10.25115/eea.v39i4.4309

Zheng, S., Li, H., \& Wu, X. (2013). Network resources and the innovation performance. Management Decision, 51(6), 1207-1224. https://doi.org/10.1108/MD-02-2012-0102 